\title{
Ketertarikan Anaxipha longipennis Serville (Orthoptera: Gryllidae) terhadap Beberapa Jenis Gulma di Sawah sebagai Tempat Bertelur
}

\author{
SRI KARINDAH*, ARDIYANTI PURWANINGSIH, ANIS AGUSTIN \\ DAN LUDJI PANTJA ASTUTI
}

Fakultas Pertanian Universitas Brawijaya

Jalan Veteran, Malang 65145

(diterima Desember 2010, diterima Februari 2011)

\begin{abstract}
ABSTRAK
Ketertarikan Anaxipha longipennis Serville (Orthoptera: Gryllidae) terhadap Beberapa Jenis Gulma di Sawah sebagai Tempat Bertelur. Jengkerik Anaxipha longipennis Serville (Orthoptera: Gryllidae) adalah salah satu predator generalis di habitat sawah yang menyukai telur pelipat daun padi dan serangga-serangga kecil lain seperti wereng-wereng padi. Jengkerik betina menyisipkan telurnya pada batang atau pelepah daun padi dan gulma-gulma di habitat sawah. Tempat bertelur yang disukai akan menjamin keberlanjutan keberadaan jengkerik di habitat sawah. Pada penelitian ini telah dicoba untuk mengetahui jenis gulma yang dipilih sebagai tempat bertelur selain pada tanaman padi. Tujuh belas species gulma dan padi telah dipaparkan pada 5 pasang jengkerik sebagai tempat bertelur pada suatu percobaan memilih secara bebas. Sembilan spesies gulma telah dipilih sebagai tempat bertelur oleh A. longipennis selain padi. Telur diletakkan paling banyak pada padi dan berturut-turut diikuti pada Monochoria vaginalis, Cyperus rotundus, C. iria, Echinochloa colonum, E. crusgalli, Eleusine indica, Fimbristylis miliacea, Imperata cylindrica, dan Limnocharis flava. Sedangkan Alternanthera sessilis, Ludwigia adscendens, Commelina diffusa, Leersia hexandra, Leptochloa chinensis, $P$. repens, Ageratum conyzoides dan Sonchus arvensis tidak dipilih oleh A. longipennis sebagai tempat bertelur.
\end{abstract}

KATA KUNCI: Anaxipha longipennis, tempat bertelur, padi, gulma

\begin{abstract}
The Oviposition Preference of Anaxipha longipennis Serville (Orthoptera: Gryllidae) on Several Weeds in Rice Field. Anaxipha longipennis Serville (Orthoptera: Gryllidae) is one of the generalist predator in rice habitat that has a potential as a biological control agents of rice leaf folder eggs and small insects such as rice hoppers. Females insert their eggs in plant tissue. The female's oviposition site is important for the subsequent distribution of the cricket. Oviposition preference on 17 weeds species from rice habitat were tested in a free choice experiment in the laboratory. There was strong evidence to conclude that the cricket preferred certain plant for laying eggs. In free choice experiment nine species of weeds were preferred by $A$. longipennis for laying their eggs instead of rice. The preferred species were ranked as follows: rice, Monochoria vaginalis, Cyperus rotundus, $C$. iria, Echinochloa colonum, E. crusgalli, Eleusine indica, Fimbristylis
\end{abstract}

\footnotetext{
*Korespondensi:

Telp.: +62-341-575843,

Faks: +62-341-569237, E-mail: karindah@ub.ac.id
} 
miliacea, Imperata cylindrica, and Limnocharis flava. Whereas Ageratum conyzoides, Alternanthera sessilis, Commelina diffusa, Leersia hexandra,

Leptochloa chinensis, Ludwigia adscendens, Panicum repens, and Sonchus arvensis were not preferred in free-choice test.

KEY WORDS: Anaxipha longipennis, oviposition sites, rice, weed

\section{PENDAHULUAN}

Predator generalis telah mendapatkan perhatian lebih pada saat ini sebagai agens hayati (Symondson et al. 2002). Berdasarkan mangsanya predator dibagi menjadi dua, yaitu predator spesifik dan predator generalis (Settle \& Ariawan 1997). Nilai lebih predator generalis dibandingkan dengan predator spesifik antara lain mampu beradaptasi dengan mudah dan dapat berkembang meskipun mangsa utama tidak tersedia, sehingga mampu berkembang lebih awal daripada mangsanya. Adaptasi ini dilakukan dengan memangsa serangga pengurai dan serangga pemakan plankton yang ada di sekitarnya. Untuk mencegah berkurangnya potensi dan populasi predator generalis yang ada, perlu dilakukan pelestarian atau konservasi terhadap predator tersebut.

Pelestarian predator generalis dapat dilakukan dengan mengembang biakkan predator secara alami dan meningkatkan peranan predator tersebut dengan memanfaatkan faktor biotik dan abiotik di sekitar tanaman. Habitat di sekitar lahan pertanian merupakan tempat pengungsian bagi banyak serangga predator dan parasitoid, jika kondisi di lahan pertanaman berubah drastis seperti waktu panen dan bera. Habitat itu juga merupakan habitat bagi mangsa atau inang alternatif musuh alami serta menyediakan pakan tambahan seperti nektar dan tepung sari (Sosromarsono \& Untung 2000). Gulma atau rumput-rumputan memiliki polen yang dapat dimanfaatkan untuk pelestarian parasitoid dan predator sebagai sumber pakan, tempat berlindung dan berkembang biak sebelum inang atau mangsa utama ada di pertanaman (Laba \& Kartohardjono 1998).

Anaxipha longipennis Serville adalah salah satu predator generalis yang dapat ditemukan pada ekosistem pertanaman padi. Pada habitat tersebut jengkerik ini merupakan predator yang efektif untuk telur lepidoptera dan nimfa wereng padi (Heong 2002). Anaxipha sp. dan Mettioche vittaticollis (Stal) dikenal sebagai predator telur dari Mythimna separata, penggerek batang Chilo suppresalis (Rubia \& Shepard 1987); Chilo polychrysus, Spodoptera litura, Hydrelia sasaki (Shepard et al. 1994), telur pelipat daun Cnaphalocrosis medinalis (de Kraker 1996) dan predator nimfa wereng padi (Rubia \& Shepard 1987; Shepard et al. 1994). Hasil penelitian IRRI (Heong 2002) menunjukkan bah- 
wa habitat yang didominasi gulma Paspalum conjugatum banyak ditemukan jengkerik $A$. longipennis dan $M$. vittaticollis yang hidup bersama-sama. Jengkerik ini tergolong pada subfamili Trigonidiinae, famili Gryllidae dan ordo Orthoptera (CSIRO 1970).

De Kraker (1996) menjelaskan bahwa selama di pertanaman padi, $A$. longipennis dan $M$. vittaticolis aktif memangsa telur hama penggulung daun Cnaphalocrosis medinalis lebih dari 90\%. Heong (1991 dalam De Kraker 1996) menambahkan bahwa kemampuan predasi jengkerik $A$. longipennis dan $M$. vittaticolis, berperan utama dalam menurunkan telur Cnaphalocrosis dan Marasmia patnalis. Kedua predator generalis ini mempunyai kemampuan predasi yang lebih tinggi dibandingkan dengan Micraspis sp., Ophionea sp., dan Paederus sp. terhadap nimfa wereng coklat (Karindah 2006).

Predator A. longipennis memiliki potensi yang baik sebagai pemangsa telur penggerek batang padi dan nimfa wereng coklat (De Kraker 1996) sehingga perlu dilakukan upaya pelestarian dengan mengembangkan dan mempertahankan habitatnya di lapangan. Upaya tersebut diantaranya dapat dilakukan dengan mengetahui jenis tumbuhan inang yang dapat berperan sebagai tempat peletakan telur (oviposisi) bagi A. longipennis.

Pada areal persawahan, A. longipennis sering dijumpai pada tanaman padi dan gulma yang berada di pematang. Beberapa gulma ini digunakan sebagai inang alternatif yang menyediakan mangsa alternatif dan tempat berlindung apabila tanaman utama tidak tersedia. Pengelolaan gulma perlu dilakukan, sehingga populasi $A$. longipennis dapat dipertahankan di areal persawahan. Pemilihan beberapa gulma di pematang sawah yang tepat sebagai inang alternatif dari A. longipennis diharapkan mempermudah pengembangbiakannya di lapangan. Untuk itu perlu diketahui ketertarikan $A$. longipennis pada beberapa jenis gulma berdaun sempit dan gulma berdaun lebar yang ada di pertanaman padi atau di pematang sebagai tempat bertelur atau oviposisi.

\section{BAHAN DAN METODE}

Ketertarikan A. longipennis pada beberapa gulma sebagai tempat bertelur secara bebas telah dilakukan di Laboratorium Hama Jurusan Hama dan Penyakit Tumbuhan, Fakultas Pertanian, Universitas Brawijaya Malang sejak Juni 2006 sampai dengan Januari 2007.

A. longipennis sebagai bahan uji ditangkap dari lahan pesemaian padi berumur 3 minggu di daerah Pakisaji, Malang pada stadia nimfa dengan menggunakan jaring serangga (sweepnet). Nimfa dipelihara hingga mencapai stadium imago dalam kurungan yang berukuran $30 \mathrm{~cm}$ x $30 \mathrm{~cm}$ x 40 $\mathrm{cm}$ dan diberi pakan nimfa wereng 
coklat (pada semaian padi), kuning telur, dan wortel serut. Sebagai serangga uji digunakan imago A. longipennis yang berumur 10 hari dan memiliki alat tubuh yang lengkap, yaitu antenna, tungkai dan ovipositor tidak memiliki kecacatan. A. longipennis dipelihara di laboratorium pada suhu $26^{\circ} \mathrm{C}-28^{\circ} \mathrm{C}$.

Beberapa jenis gulma, yaitu Ageratum conyzoides (bandotan), Alternanthera sessilis, Commelina diffusa (brambangan), Cyperus iria (rumput mendong), C. rotundus (teki), Echinochloa colonum (rumput kusa-kusa), E. crussgalli (jawan), Eleusine indica (rumput belulang), Fimbristylis miliacea (tumbaran), Imperata cylindrica (alang-alang), Leersia hexandra (benta), Leptochloa chinensis (timunan), Limnocharis flava (genjer), Ludwigia adcendens (tapak dara), Monochoria vaginalis (enceng lembut), Panicum repens (lempuyangan), dan Sonchus arvensis (tempuyung) diperoleh dari pematang sawah. Identifikasi gulmagulma tersebut dilakukan berdasarkan Kostermans et al. (1987). Masingmasing gulma tersebut selanjutnya ditanam pada polibag berdiameter 10 $\mathrm{cm}$ menggunakan media tanah dan kompos dengan perbandingan $2: 1$. Pada tiap polibag ditanamkan rumpun yang terdiri dari lima batang. Penanaman padi dimulai dengan merendam benih padi dalam air hingga benih tersebut bertunas. Selanjutnya benih ditanam pada polibag berdiameter 10 cm dengan menggunakan media tanam berupa campuran tanah dan kompos dengan perbandingan $2: 1$. Padi yang digunakan pada penelitian ini adalah varietas IR 64. Padi ini digunakan sebagai pembanding pada uji ketertarikan A. longipennis terhadap beberapa gulma sebagai tempat oviposisi. Gulma dan tanaman padi dipelihara di rumah kasa sampai siap dipergunakan dalam penelitian.

Pengujian ketertarikan A. longipennis terhadap beberapa jenis gulma dan tanaman padi sebagai tempat bertelur ini dilakukan dengan memasukkan 17 jenis gulma dan tanaman padi pada polibag dalam kurungan plastik berukuran $80 \mathrm{~cm}$ x $80 \mathrm{~cm}$ x $60 \mathrm{~cm}$ dan meletakkannya secara melingkar. Gulma dan padi sebelum dimasukkan ke dalam kurungan pengujian diperiksa terlebih dahulu dan diusahakan untuk membersihkannya agar tidak terdapat serangga atau laba-laba. Selanjutnya ke dalam kurungan tersebut dilepaskan 5 pasang imago A. longipennis. Pengujian ini dilakukan pada 3 kurungan dan digunakan sebagai 3 kali ulangan. Selama percobaan A. longipennis diberi pakan berupa wortel parut (Rubia \& Shepard 1987) dan cacahan kuning telur yang diganti setiap 24 jam sekali. Pakan tersebut diletakkan di tengah lingkaran dari jajaran melingkar polibag dengan padi dan gulma yang diuji.

Gulma dan tanaman padi diambil dan diganti setelah $3 \times 24$ jam dan diharapkan A. longipennis telah mela- 
kukan oviposisi. Penggantian gulma ini dilakukan sebanyak 5 kali selama 15 hari. Jumlah telur yang diletakkan A. longipennis pada gulma dan tanaman padi tersebut diamati dengan melakukan pembedahan di bawah mikroskop binokulair. Dari jumlah telur yang diletakkan per tanaman dapat dianalisis ketertarikan A. longipennis pada berbagai gulma dan tanaman padi.

Data yang diperoleh dari pengujian ketertarikan A. longipennis terhadap beberapa gulma sebagai tempat bertelur atau oviposisi berupa perhitungan jumlah telur yang di letakkan oleh A. longipennis pada setiap gulma dan dibandingkan dengan jumlah telur yang diletakkan pada tanaman padi. Data tersebut dianalisis dengan menggunakan analisis non parametrik Kruskal Wallis dengan tingkat kepercayaan 95\%. Sebagai data penunjang diamati pula kekerasan batang dan jumlah trikhoma dari bagian tanaman padi dan spesies gulma uji di tempat yang biasa A. longipennis meletakkan telurnya. Kekerasan batang dilakukan pengukuran dengan menggunakan penetrometer SUR Berlin PNR 6.

\section{HASIL DAN PEMBAHASAN}

Telur A. longipennis berbentuk silinder, berwarna putih transparan dan disisipkan satu per satu pada batang bagian bawah tanaman atau di pelepah daun. Adanya telur dalam batang tanaman biasanya ditandai dengan adanya luka tusuk ovipositor yang ditutupi oleh kotoran hasil sekresi dari $A$. longipennis dan butiran tanah atau ada bagian dari ujung telur yang menonjol pada batang tanaman sehingga dapat terlihat dari luar.

Hasil analisis nonparametrik Kruskal Wallis pada uji ketertarikan peletakan telur A. longipennis terhadap 17 jenis gulma dan padi menunjukkan adanya pengaruh yang nyata dari jenis tumbuhan terhadap jumlah telur yang diletakkan (d.f = 17, P =0,002). Jengkerik A. longipennis meletakkan telur dengan jumlah yang berbeda nyata pada padi dan beberapa jenis gulma. $A$. longipennis memilih 9 jenis gulma selain tanaman padi sebagai tempat meletakkan telurnya, sedangkan 8 jenis gulma lainnya yang diuji tidak dipilih sebagai tempat bertelur. Jumlah maksimum dan rerata telur yang disisipkan pada batang padi atau gulma disajikan pada Tabel 1. Selain padi, jenis gulma yang dipilih berturut-turut adalah $M$. vaginalis, $C$. iria, $C$. rotundus, $F$. miliacea, E. colonum, E. crusgalli, E. indica, I. cylindrica dan L. flava. Sedangkan A. conyzoides, A. sessilis, L. adscendens, $C$. diffusa, $L$. hexandra, L. chinensis, P. repens, dan $S$. arvensis tidak dipilih oleh $A$. long ipennis sebagai tempat bertelur.

Hasil analisis regresi menunjukkan tidak adanya hubungan yang nyata antara jumlah telur yang diletakkan dengan kekerasan batang padi atau gulma yang diuji $(\mathrm{P}=0,274)$. Demiki- 
an pula tidak ada hubungan yang nyata antara jumlah telur yang diletakkan $A$. longipennis dengan jumlah trikhoma pada padi atau gulma yang diuji $(\mathrm{P}=$ 0,193). Namun A. longipennis cenderung memilih batang tumbuhan sebagai tempat peneluran.

Hasil percobaan membuktikan bahwa beberapa gulma dapat dipilih sebagai tempat bertelur sama baiknya dengan tanaman padi. Pemilihan tempat bertelur oleh predator dapat dipengaruhi oleh keberadaan mangsa, tanda-tanda adanya mangsa pada tumbuhan atau sifat-sifat tumbuhan itu sendiri (Sigsgaard 2004). Hasil pengujian menunjukkan bahwa $A$. longipennis mau melakukan oviposisi pada beberapa jenis gulma yang ada di sekitar lahan persawahan selain pada tanaman padi. $M$. vaginalis merupakan gulma yang hidup di air dan berada di sekitar tanaman padi di dalam petak sawah, demikian pula dengan $C$. iria, E. crusgalli, E. colonum, F. miliacea, dan L. flava. Gulma yang tumbuh di sekitar habitat asli A. longipennis ini mempermudah A. longipennis untuk mencari pakan setelah melakukan peneluran dan menyediakan pakan yang cukup bagi keturunannya. Sedangkan C. rotundus, E. indica, I. cylindrica, A. conyzoides, L. hexandra, S. arvensis dan $P$. repens kebanyakan tumbuh di tepi pematang sawah. A. sessilis, $C$. diffusa, L. adscendes, dan L. chinensis biasa tumbuh dipetak sawah maupun

Tabel 1. Rerata jumlah telur $A$. longipennis yang diletakkan pada padi dan tujuh belas spesies gulma dengan berbagai jumlah trikhoma dan kekerasan relatif batang gulma

\begin{tabular}{|c|c|c|c|c|c|c|}
\hline No & Tumbuhan yang diuji & $\begin{array}{c}\text { Jumlah } \\
\text { maksimum } \\
\text { telur yang } \\
\text { diletakkan } \\
\text { (5 pasang) }\end{array}$ & Median & Rerata \pm SE & $\begin{array}{l}\text { Jumlah } \\
\text { trikhoma } \\
\text { per } \mathrm{cm}^{2}\end{array}$ & $\begin{array}{c}\text { Kekerasan } \\
\text { relatif } \\
\text { batang } \\
(\mathrm{mm})\end{array}$ \\
\hline 1. & Oriza sativa & 33,00 & 32,00 & $29,00 \pm 3,51$ & 1,00 & 0,47 \\
\hline 2. & Monochoria vaginalis & 33,00 & 18,00 & $19,33 \pm 7,54$ & 1,67 & 3,30 \\
\hline 3. & Cyperus iria & 15,00 & 2,00 & $16,00 \pm 3,79$ & 0,48 & 0,90 \\
\hline 4. & Cyperus rotundus & 20,00 & 15,00 & $15,00 \pm 2,89$ & 2,22 & 1,03 \\
\hline 5. & Fimbristylis miliacea & 13,00 & 0,00 & $4,33 \pm 4,33$ & 2,50 & 1,00 \\
\hline 6. & Echinochloa colonum, & 7,00 & 6,00 & $6,00 \pm 0,58$ & 1,67 & 0,37 \\
\hline 7. & Echinochloa crusgalli & 7,00 & 5,00 & $5,00 \pm 1,15$ & 3,23 & 0,00 \\
\hline 8. & Eleusine indica & 7,00 & 5,00 & $4,67 \pm 1,45$ & 3,89 & 0,23 \\
\hline 9. & Imperata cylindrica & 2,00 & 0,00 & $0,67 \pm 0,67$ & 9,44 & 0,00 \\
\hline 10. & Limnocharis flava & 1,00 & 0,00 & $0,33 \pm 0,33$ & 1,00 & 3,87 \\
\hline 11 & Ageratum conyzoides & 0,00 & 0,00 & $0,00 \pm 0,00$ & 131,67 & 0,43 \\
\hline 12. & Alternanthera sessilis & 0,00 & 0,00 & $0,00 \pm 0,00$ & 3,33 & 0,50 \\
\hline 13. & Commelina diffusa & 0,00 & 0,00 & $0,00 \pm 0,00$ & 4,58 & 0,47 \\
\hline 14. & Leptochloa chinensis & 0,00 & 0,00 & $0,00 \pm 0,00$ & 5,00 & 0,10 \\
\hline 15. & Leersia hexandra & 0,00 & 0,00 & $0,00 \pm 0,00$ & 1,67 & 0,13 \\
\hline 16. & Ludwigia adscendes & 0,00 & 0,00 & $0,00 \pm 0,00$ & 1,25 & 2,30 \\
\hline 17. & Panicum repens & 0,00 & 0,00 & $0,00 \pm 0,00$ & 3,33 & 0,23 \\
\hline 18. & Sonchus arvensis & 0,00 & 0,00 & $0,00 \pm 0,00$ & 5,00 & 0,10 \\
\hline
\end{tabular}


di pematang. Menurut Craigh et al. (2000), serangga betina akan meletakkan keturunannya di tempat dengan peluang hidup tinggi, selain itu pemilihan tempat untuk bertelur yang tepat dilakukan dengan tujuan agar keturunan baru yang biasanya belum aktif bisa mendapatkan pakan cukup dan tersedia di sekitarnya (Sadeghi \& Gilbert 2000).

Selain kedekatan letak gulma dengan mangsanya $A$. longipennis cenderung memilih batang tumbuhan sebagai tempat peneluran yang tidak banyak mempunyai trikhoma. Hal ini sesuai dengan pendapat Kogan (1975), dalam Mudjiono (1998) bahwa salah satu faktor fisik tanaman mempengaruhi proses hinggap, makan dan peletakkan telur serangga antara lain adalah bentuk, ukuran dan kepadatan trikhoma. Keadaan sebaliknya terjadi pada Coleomegilla maculata yang lebih memilih untuk meletakkan telur pada sejenis tumbuhan liar, yaitu Abutiton theopharasti, karena tumbuhan liar tersebut memiliki trikhoma yang kelenjarnya menghalangi predator lain mendapatkan telur-telur kumbang $C$. maculata untuk dimangsa (Griffin \& Yeargan 2002). A. longipennis juga tidak mau meletakkan telur pada $S$. arvensis sama seperti pada $A$. conyzoides, $L$. hexandra, $L$. chinensis, $L$. adscendens, atau $P$. repens. Hasil pengamatan yang dilakukan, A. longipennis ini tidak mau meletakkan telur mungkin disebabkan adanya cairan atau getah yang dikeluarkan oleh $S$. arvensis apabila terkena tusukan ovipositor dari A. longipennis. Kandungan senyawa kimia pada jenis gulma yang disukai atau yang tidak disukai sebagai tempat bertelur belum diketahui pengaruhnya terhadap kesukaan A. longipennis meletakkan telurnya. Menurut Tumlinson (1988) terdapat semiochemical yang mengatur oviposisi serangga. Semiochemical adalah senyawa kimia yang dapat membantu serangga mendapatkan lokasi inang atau mangsa bagi parasitoid atau predator, yang dihasilkan oleh inang atau mangsa, ataupun oleh tumbuhan di mana mereka tinggal.

Selain sebagai tempat berlindung dan sumber pakan tambahan, tumbuhan liar juga seringkali dipilih sebagai tempat bertelur. Hasil penelitian ini dapat menjelaskan bahwa beberapa jenis gulma diperlukan bagi jengkerik predator A. longipennis sebagai tempat berkembang biak. Keberadaan spesiesspesies gulma tertentu akan dapat mendukung terjadinya pelestarian musuh alami. Gulma yang termasuk organisme pengganggu bagi tanaman budidaya sesungguhnya mempunyai arti bagi kehidupan heksapoda predator dan parasitoid.

\section{KESIMPULAN}

Jengkerik A. longipennis meletakan telur paling banyak pada padi dan berturut-turut diikuti pada $M$. vagina- 
lis, C. rotundus, C. iria, E. colonum, E. crusgalli, E. indica, F. miliacea, I. cylindrical, dan L. flava. Gulma $A$. sessilis, L. adscendens, C. diffusa, $L$. hexandra, L. chinensis, $P$. repens, A. conyzoides dan $S$. arvensis tidak dipilih oleh A. longipennis sebagai tempat bertelur.

\section{DAFTAR PUSTAKA}

Commonwealth Scientific and International Research Organization (CSIRO). 1970. Insects of Australia: A Textbook for Students and Research Workers. Melbourne: University Press, Victoria, Australia.

Craigh TK. Joanne S, Cathleen G Warren JDH James dan Craigh V. 2000. The influence of host plant variation and intraspesific competition on oviposition preference and offspring performance in host races of Eurosta solidaginis. Ecological Entomology 25: 7-18.

De Kraker J. 1996. The Potential of Natural Enemies to Suppress Rice Leaffolder Populations. [PhD Thesis]. The Netherlands: Wageningen Agricultural University.

Griffin ML. dan Yeargan KV. 2002. Oviposition site selection by the spotted lady beetle Coleomegilla maculata (Coleoptera: Coccinellidae): choices among plant species. Environ. Entomol 31:107111.

Heong KL. 2002. Arthropod diversity: looking beyond the ricefields. www.irri.org/ Science.htm. [diakses 21 Juni 2002]
Karindah S. 2006. The Use of Weeds Plant Species to Enhance the Conservation of Metioche vittaticollis Stal (Orthoptera: Gryllidae), Generalist Predator of Rice Hoppers [disertasi]. Malang: Program Pasca Sarjana Universitas Brawijaya.

Kostermans AJGH, Wirjahardja S dan Dekker RJ. 1987. The weeds: description, ecology and control. In: Mohamad Soerjani, A. J. G. H. Kostermans and Gembong Tjitrosoepomo (ed), Weeds of Rice in Indonesia. Jakarta: Balai Pustaka. p 24-566.

Laba IW. dan Kartohardjono A. 1998. Pelestarian parasitoid dan predator dalam pengendalian hama tanaman. Jurnal Penelitian dan Pengembangan Pertanian XVII: 121-129.

Mudjiono G. 1998. Hubungan Timbal Balik Serangga - Tumbuhan. Ma lang: Lembaga Penerbitan Fakultas Pertanian Universitas Brawijaya.

Rubia EG. dan Shepard BM. 1987. Biology of Metioche vittaticollis (Stal.) (Orthoptera: Gryllidae), a predator of rice pest. Bull Ent. Res. 77:669- 676.

Sadeghi H. dan Gilbert T. 2000. Oviposition preferences of aphidophagus hoverflies. Ecological Entomology 25: 91-100.

Settle W. dan Ariawan H.1997. Mengelola hama padi daerah tropis melalui konservasi musuh alami generalis dan mangsa alternatif. Malang: Program Nasional Pengendalian Hama Terpadu Departemen Pertanian Fakultas Pertanian Universitas Brawijaya. 
Shepard BM, Barion AT dan Litsinger JA. 1994. Mitra Petani, Serangga Laba-laba dan Patogen yang Membantu. Kasumbogo Untung \& Samino Wirjosuharjo, penerjemah. Los Banos: International Rice Research Institute.

Sigsgaard L. 2004. Oviposition preference of Anthocoris nemorum and A. nemoralis for apple and pear. Entomol. Exp. Appl. III: 215-223.

Sosromarsono S. dan Untung K. 2000. Keanekaragaman hayati artropoda predator dan parasitoid di Indonesia serta pemanfaatannya.
Di dalam: Prosiding Simposium Keanekaragaman Hayati Artropoda pada Sistem Produksi Pertanian; Cipayung, 16-18 Oktober 2000. Cipayung: PEIKEHATI p. 33-46.

Symondson WOC, Sunderland KD dan Greenstone MH. 2002. Can generalist predators be effective biocontrol agents?. Annual Rev. Entomol 47:561-594.

Tumlinson JH. 1988. Contemporary frontiers in insect semiochemical research. Journal of Chemical Ecology 14(11):2109-2130. 